been barely saleable if the grants committee had been able to suggest a compromise with the government on academic tenure, but the best it has been able to muster is a proposal that probationary periods should last for five years, not three. The committee's reminder that universities individually are always free to dismiss academics whose work is less than satisfactory will not satisfy a government persuaded that academic tenure is a charter for wrong-thinking layabouts.

The committee's arguments on research are similarly ambiguous. It is right to say that British universities are responsible for well over half of British basic research. It could have claimed the more interesting half. But it will cut very little ice with a sceptical government that, having accepted the universities' view that money should not be allocated separately for teaching and research, the committee should not be able to say how it will "be more selective" without further consultation. Worse still, the committee has to confess that its efforts will not succeed unless universities themselves become more selfconscious about their prosecution of research.

Much the same is true of the committee's case for extra funds within the university system. The case is overwhelming when the need for industrial change has become as clamant as in Britain now, yet outwardly the universities' case is little different from that of other claimants on the public purse. The coalminers of Britain, for example, are flush with arguments about the strategic importance of stable mining communities. The best hope for the immediate future is that the government may listen to what the grants committee has been saying for long enough to provide a chance for internal change to be engendered. The danger is that the government will lose patience.

The most serious gap, and thus the most serious weakness, of the universities' claim on the British Government is that the committee has so little to say on their behalf about their constitution, and about relationships between the public and private sectors. Yet the greatest iniquities of the past few years are embodied in the ways in which universities have been told how many students they may teach and are now being moulded on patterns specified from without. Academics apparently willing to go to the stake in defence of academic freedom supposedly bound up in the rules of tenure seem much less eager to defend their institutions on these more important counts. The only remedy is that constitutional autonomy should be backed by financial autonomy, and that academic institutions - public as well as private - should be allowed to make their way in the world by the reputations they are able to acquire in the eyes of students and students' employers. If, in the arrangement of financial autonomy for universities (and polytechnics), it were possible also to solve the government's problem of the blank cheque - the fear that more students must mean extra maintenance costs - it might be possible to look forward in Britain to a system of higher education that would change to meet external needs without external prodding, and which would be free from the attributes of academic class-distinction that now compromise the good work that individual institutions do.

In due course, the grants committee and its opposite number for the public sector will come to recognize that such a solution is inevitable. So, too, will the government. For the time being, however, the best that can be hoped for is that higher educational institutions, public as well as private, will recognize the potential value of diversity and their masters the importance of autonomy. The grants committee's document refers to a scheme the British Government was canvassing earlier this year that would have given some universities a fixed budget, no other marching orders but an exhortation to make what they could of their resources. Cryptically, the committee says it will give its opinion on the scheme "if asked". Appearances to the contrary, its opinion should be that everybody would stand to gain from an experiment in autonomy along lines like these. Why not offer an opportunity for one university and one polytechnic to try their hands at freedom within the confines of an inflation-proofed public subvention? Or is everybody afraid of being overwhelmed by the rush of applicants?

\section{Help for Argentina?}

The plight of Argentinian science (see page 201) deserves widely to be recognized.

IT is easy for those in developed countries to regard the sorry state of Argentinian science with the contempt familiarly accorded the efforts of developing countries to appear scientifically sophisticated; building biotechnology centres without biotechnologists to populate them, or research reactors when there are no nuclear physicists. But Argentina is different. It has produced a large number of first-rate scientists (many of whom now work in the United States or Europe) and it has made a not unrespectable start at industrialization, helped by near self-sufficiency in petroleum and a major surplus in agricultural products. Argentina is not a banana republic - indeed, until December of last year, it was not even a republic. And that is crucial to understanding the special nature of Argentinian science, and why it is in a different mess from that of other developing countries.

In addition to its major credentials of repression, murder and the Falklands war, the military regime that seized power in $\mathbf{1 9 7 6}$ can claim credit for the dismantling of Argentina's scientific institutions, the universities in particular. The potential remains, but its realization is further away than ever. The return to democracy, still a source of wonder and justifiable admiration in the Western world, has brought with it a sweeping change of attitudes. Some of the most competent and knowledgeable people one could expect to find in any government have been put in charge of repairing Argentine science, but the task requires more than clear thinking. It is difficult to have a science policy without money, and Argentina has none. And the new government will not indulge the luxury of investing long-term in science and higher education while its overseas debt amounts to $\$ 50,000$ million and while it has to keep borrowing more to pay the outstanding interest.

So what can others do to help? And why should they bother? External financial aid for scientific institutions would be invaluable, but is unlikely to materialize quickly. Yet that is no reason why the question should not be considered. In the past few days, the World Bank has made a loan of $\$ 25$ million to the People's Republic of China to help with the foundation of a network of institutes for agricultural research. Even allowing for the way in which China has become the apple of Western eyes, and for the fact that Argentina still has to meet the tough monetary conditions prescribed by the World Bank's sister organization, the International Monetary Fund, the case for a special loan is powerful.

The extent of the damage done to Argentinian science - and the real potential for excellence - has magnified the value of more informal contributions. People in the United States and Europe will do far more than they can perhaps imagine possible for restoring science in Argentina simply by participating in conferences there, by spending time there as visiting professors or teaching short courses, or simply by keeping in contact with Argentinian scientists who have been isolated by the recent events, and who face enormous difficulties in what is elsewhere the effortless task of keeping up with current scientific information. The shortage of foreign journals, always a problem in developing countries, has been greatly exacerbated by the military regime's policy of choking off the universities.

To those in Britain who may mumble about the Falklands war and about cooperation with a nation still technically at war, it is worth noting that the best assurance of peace and reasonableness on all sides is the presence of a democracy in Argentina. It was a desparate totalitarian regime that launched the Falklands war, an awkward legacy for the new government. And at least among educated Argentinians, one is more likely to hear joking references to Britain's "enemy" status than talk of vengeance. Anything that can be done to bolster Argentina's democracy, and its commitment under President Raul Alfonsin to make education, rather than weapons, the foundation of its national security, is a step in the right direction for everyone concerned. $\square$ 